\title{
Cryoballoon Ablation Therapy
}

National Cancer Institute

\section{Source}

National Cancer Institute. Cryoballoon Ablation Therapy. NCI Thesaurus. Code C127818.

An image-guided, minimally invasive surgical technique that uses a balloon-tipped

catheter to deliver cryogenic energy to targeted tissue, resulting in cell death secondary to cryogenic injury. 